KS. PIOTR ROSZAK ${ }^{1}$

Uniwersytet Mikołaja Kopernika w Toruniu

piotrroszak@umk.pl

\title{
„Mysterium” w euchologii hiszpańsko-mozarabskiej: od epistemologii liturgicznej do eklezjalnej praxis ${ }^{2}$
}

Liturgię hiszpańsko-mozarabską spowija mrok misteryjności: nie znamy zbyt wiele szczegółów dotyczących sposobów jej celebracji, a historycy spierają się co do charakteru tożsamości tych, którzy ocalili ryt od zapomnienia - mozarabów. Żyli oni w trudnych realiach społeczno-politycznych, które zapanowały na Półwyspie Iberyjskim po przekroczeniu Cieśniny Giblartarskiej przez Arabów w 711 roku $^{3}$. Zewnętrznie przyjęli zwyczaje nowych panów Iberii - poddali się arabizacji językowej i przejęli pewne ich zwyczaje - ale pozostali chrześcijanami. Żyli zmieszani z Arabami, stąd określenie „mozarabowie” odnosi się do tych, którzy są „podobni do Arabów”, musta’rib (aczkolwiek samo to określenie

${ }^{1}$ Ks. Piotr Roszak - dr hab. teologii, adiunkt w Zakładzie Teologii Fundamentalnej i Religiologii Wydziału Teologicznego Uniwersytetu Mikołaja Kopernika w Toruniu, profesor stowarzyszony Uniwersytetu Nawarry w Pampelunie (Hiszpania), redaktor naczelny czasopisma „Scientia et Fides” oraz redaktor serii wydawniczej Scholastica Thoruniensia, w której zamieszczane są tłumaczenia komentarzy biblijnych autorów średniowiecznych.

${ }^{2} \mathrm{~W}$ artykule wykorzystano informacje uzyskane przy realizacji projektu Chrystus vs. Mahomet. Chrystologia mozarabska w świetle źródeł liturgicznych rytu hiszpańskiego finansowanego przez Narodowe Centrum Nauki na podstawie decyzji nr DEC-2011/01/D/HS1/00712.

${ }^{3}$ A. Christys, Christians in Al-Andalus 711-1000, Routledge, London-New York 2010. 
ma genezę późniejszą i pochodzi z terenów chrześcijańskich, gdyż przez Arabów byli określani jako „Nazarejczycy” bądź „Ludzie Księgi”)

Mozarabowie pozostali wierni swej wierze, jednak konsekwencjami tego były znaczące koszty ekonomiczne, jakie musieli ponosić (możliwość sprawowania kultu chrześcijańskiego była związana ze specjalnym podatkiem), czy też doskwierające wykluczenie społeczne (niemożliwość awansu na pewne szczeble administracji), którego doświadczali na co dzień ${ }^{5}$. Sprawowali misteria chrześcijańskiej wiary w szczególnym napięciu hermeneutycznym: odczytywali je jako rzucające światło na ich aktualną sytuację egzystencjalną, w której wyznawanie wiary w Chrystusa niosło z sobą szereg następstw społecznych ${ }^{6}$. Dialektyka widzialności misterium była charakterystyczną cechą ich celebracji, które dokonywały się w szczególnych przestrzeniach liturgicznych właściwych dla architektury mozarabskiej ${ }^{7}$. Swiątynie składające się $\mathrm{z}$ wielu małych brył o niewielkiej ilości światła budowane były na planie labiryntu, aby uzmysłowić, że jedynym znającym drogę wyjścia z zaplątanych ludzkich historii (również tej społeczno-politycznej) jest Chrystus obecny dla mozarabów w tajemnicy sprawowanej liturgicznie ${ }^{8}$.

Liturgia hiszpańska jest określeniem szerokim, gdyż obejmuje nie tylko okres mozarabski upływający pod znakiem napięć chrześcijańsko-muzułmańskich i kontrowersji adopcjanizmu' ${ }^{9}$ lecz także obejmuje wcześniejszy okres

${ }^{4}$ E. Lapiedra Poświęca temu zagadnieniu obszerne studium Cómo los musulmanes llamaban a los cristianos hispánicos, Alicante 1997; por. Y. Beale-Rivaya, The history and evolution of the term „mozarab”, „Imago Temporis. Medium Aevum” 4 (2010), s. 51-71.

${ }^{5}$ J. F. Rivera Recio, Formas de convivencia y heterodoxias en el primer siglo mozárabe, [w:] Historia mozárabe, Instituto de Estudios Visigotico-Mozarabes de San Eugenio, Toledo 1978, s. 3-16; M. A. Gallego, The languages of medieval Iberia and their religious dimensión, „Medieval Encounters” 1 (2003), s. 107-139.

${ }^{6}$ L. Peñarroja, Cristianos bajo el Islam: los mozárabes hasta la Reconquista de Valencia, Gredos, Madrid 1993.

${ }^{7}$ J. Yarza, Arte asturiano. Arte mozárabe, Cáceres 1985.

${ }^{8}$ Por. P. Roszak, Mozarabowie - niespokojna mniejszość. O duchowości czasów bycia w mniejszości, „Teologia i Człowiek” 13 (2009), s. 79-98.

${ }^{9} \mathrm{Na}$ ten spór możemy patrzeć w perspektywie dialogu z teologią islamu - por. D. Urvoy, $\mathrm{La}$ pensée religieuse des Mozarabes face à l'Islam, „Traditio” 39 (1983), s. 419-432; L. Ranera, Jesús 
patrystyczny i wizygocki związany z aktywnością trzech głównych centrów kościelnych tamtego czasu (Toledo, Sewilli i Tarragony) ${ }^{10}$. Mozarabowie ocalili tradycję liturgiczną kościołów hiszpańskich pierwszych wieków chrześcijaństwa, która pozostawała pod dużym wpływem nie tylko tradycji gallikańskiej, lecz także afrykańskiej (i przez to wschodniej) ${ }^{11}$. Świadczy o tym wiele motywów teologicznych, które przeniknęły do euchologii hiszpańskiej i znajdują swój wyraz w formularzach poszczególnych mszy ${ }^{12}$. Czy ma to znaczenie dla rozumienia liturgii w kluczu misterium i sakramentu? Jak liturgia hiszpańska postrzega wzajemne relacje między mysterium i sacramentum? Na podstawie Missale Hispano-Mozarabicum postaram się przedstawić mozarabskie rozumienie misterium, które znamionuje charakterystyczna dwutorowość: skupienie na aspekcie epistemologicznym (sposób liturgicznego dotarcia do misteriów) i eklezjologiczne konotacje dla życia chrześcijańskiego. Zacznijmy od nakreślenia wzajemnych relacji między obu terminami. Czym jest „sakrament” dla mozarabów, a czym „misterium”?

\section{Mysterium in hoc sacramento: w stronę „prawdy sakramentu”}

Choć w okresie patrystycznym te dwa terminy: mysterium i sacramentum były jeszcze synonimami, to w liturgii hiszpańskiej pojawiają

y Mahoma, „Encuentros Teológicos” 7 (2007-2008), s. 106-109; M. Lázaro Pulido, Cristianismo e Islam en el pensamiento medieval. Encuentros y desencuentros, „Cauriensia” 4 (2009), s. 81-139. Szczególnie jednak zasługuje na uwagę syntetyczne opracowanie bazujące na źródłach mozarabskich: R. J. Pedrajas, Historia de los mozárabes en Al Ándalus: mozárabes y musulmanes en Al Ándalus: ¿relaciones de convivencia?, ¿o de antagonismo y lucha?, Almuzara, Córdoba 2013.

${ }^{10}$ Por. J. Pinell, Hispánica (liturgia), [w:] Diccionario Patrístico y de la Antigüedad Cristiana, dir. A. Di Bernardino, vol. II, Sígueme, Salamanca 1998², 1048-1054.

${ }^{11}$ V. Janeras, Elements orientals en la litúrgia visigótica, [w:] Miscelánea Litúrgica Catalana VI, Institut d'Estudis Catalans, Barcelona 1995, s. 93-127.

12 J. M. Ferrer, La Eucaristía en rito hispano-mozárabe. Gestualidad y ambiente para la celebración, „Toletana” 1 (1999), s. 59-88. 
się pierwsze próby określenia ich specyficznego, odrębnego teologicznie znaczenia ${ }^{13}$. Niekiedy teksty zdają się jeszcze posługiwać znamienną ambiwalencją (jak wówczas, gdy mowa o „sakramencie niebieskim” ${ }^{14}$ ), ale dominuje jednak perspektywa, w której oba koncepty wzajemnie się dopełniają. O charakterze tego powiązania teologicznego między obu terminami świadczy charakterystyczne dla tego rytu częste zestawienie ich obok siebie: określenie „sakramenty misteriów” pozostaje w harmonii ze stricte technicznym posługiwaniem się terminem „sakrament” na oznaczenie znaków sakramentalnych takich jak chrzest, namaszczenie czy przede wszystkim Eucharystia (czasem traktowana par excellence jako „Sakrament”). Ale liturgia hiszpańska dostrzega „sakramenty” również w Starym Testamencie jako czynności lub rzeczy, które posiadały głębokie znaczenie duchowe. Dlatego mówi o „sakramentach dawnego prawa” (priscae legis sacramenta) ${ }^{15}$, ale także o „wielkich tajemnicach postu” (ieiuniorum magnifica sacramenta) ${ }^{16}$. Rozpiętość znaczeniowa „sakramentu” pozostaje w służbie rozumienia tego, czym jest misterium.

\subsection{Mysterii sacramenta: relacja między misterium \\ a sakramentem w rycie hiszpańskim}

W jednej z modlitw otwierających mszę pojawia się wezwanie, aby przeżywać liturgię consideranda divinis Mysteriis sacramenta ${ }^{17}$. Oznacza to wskazanie na sakramentalny dostęp do misteriów: nie są one dostępne same w sobie, lecz zostają zapośredniczone przez ryt. Mówiąc zaś ściśle, podkreślają dwa wymiary rytu: zewnętrzny (sakrament) oraz wewnętrzny (tajemnica). W tym sensie można powiedzieć, że sakramenty zawierają misteria, są pasem transmisyjnym, przez który ten kontakt jest możliwy. Dlatego ryt będzie wskazywał na „sakrament wcielenia” (in

${ }^{13}$ C. Robles García, La liturgia mozárabe, [w:] Breviarium Goticum secundum Regulam Beatissimi Isidorii, Edición facsímil, ed. J. Paniagua, Universidad de Leon 2004.

${ }^{14}$ In Circumcisione Domini, oratio admonitionis.

${ }^{15}$ In Dominico in ramis palmarum, oratio.

${ }^{16}$ Feria VI in tertia hebdomada Quadragesimae, ad pacem.

${ }^{17}$ In III Dominico Quadragesimae, oratio admonitionis. 
sacramento incarnationis amplecteres $)^{18}$, na „ukryte sakramenty męki” (sacramenta abscondida passionis suae) ${ }^{19}$, które choć ujawniają misteria i czynią je dostępnymi, to jednak nie wyczerpują ich „tajemniczości”. Sakrament ma moment ujawniający, ale i zakrywający: również w nich ukryta jest zapowiedź-figura tego, co ma stać się udziałem chrześcijanina: „ut hoc quod his sacramentis figuratum fore cognoscitur, in nostris cordibus impleatur” ${ }^{20}$. W mszy na święto Niepokalanego Poczęcia NMP mowa jest o tym, że „mýsticis præfigurátum mystériis”21. Pełne poznanie "tajemnicy” dokona się w wymiarze eschatologicznym. Sakrament w liturgii mozarabskiej nie jest jedynie zewnętrznym znakiem odsyłającym do innych treści, lecz przestrzenią spotkania w rytualnym hodie. Jednocześnie takie pojmowanie sacramentum odsłania zainteresowanie liturgii, aby dotrzeć do tego, co jest „prawdą sakramentu”, w czyjej służbie stawia się celebracja sakramentu. Dokonuje się to na drodze moralnego oczyszczenia (post i modlitwa), dzięki ktorym objawiają się sacramenta mysteriorum ${ }^{22}$.

Z tekstów euchologicznych Missale Hispano-Mozarabicum rodzi się rozumienie „tajemnicy” jako szczególnego doświadczenia łaski i miłosierdzia, obdarowania i uczestnictwa, bliskości Boga. Dlatego liturgia stawia sobie jako naczelne zadanie uwrażliwienie wiernych, aby nie banalizowali misteriów przez to, że są niedostępne wprost (stąd wołanie o sedula mysteria ${ }^{23}$, lecz sprawowali je jako wyraz miłości Boga, który niczym przyjaciel dzielący się tajemnicami z drugim, udziela ich człowiekowi. Stąd apeluje: „dignis semper tractare mysteriis et puris pacisfisque praecordiis celebrare" 24 .

${ }^{18}$ In Circumcisione Domini, post nomina.

${ }^{19}$ Feria IV in hebdomada maiore, benedictio.

${ }^{20}$ In die Sancto Paschae, oratio admonitionis.

${ }^{21}$ In diem conceptionis sanctoe Marioe Virginis, illatio.

${ }^{22}$ Feria IV in quarta hebdomada Quadragesime, illatio.

${ }^{23}$ Por. P. Roszak, La fe: entre manifestación y secreto. En torno a la eucología hispano-mozárabe, „Scripta Theologica” 1 (2014), s. 39-58; tenże, Mozarabowie i ich liturgia, Wydawnictwo Naukowe UMK, Toruń 2015.

${ }^{24}$ Feria VI in tertia hebdómada Quadragesimae, ad pacem. 
Co to jednak znaczy traktować w sposób godny? To ukształtowanie serca, aby było w stanie unieść ciężar tajemnic Bożych, otworzyć się na ten dar. To spotkanie $\mathrm{z}$ misterium dokonujące się w sakramencie potrzebuje osadzenia w perspektywie objawienia, które dla rytu mozarabskiego nie jawi się jako wydarzenie zamknięte w historii, lecz cechując się wielką płodnością, manifestuje się w sposób uprzywilejowany w bycie Kościoła: nie tylko jego nauczaniu, lecz także właśnie w sakramentalnym działaniu. Dlatego wątki dotyczące wizji i sensu historii rzucające światło na aktualną sytuację mozarabów, którzy bronią się przed anihilacją dzięki swej liturgicznej tożsamości, jest szczególną cechą euchologii hiszpańskiej.

Liturgia hiszpańska skupia swoją uwagę na sakramentalnej celebracji misterium, co podkreśla znamienna modlitwa jednej z mszy, w której kieruje się prośbę do Chrystusa, aby „Vos mystérii et ínstruat et múniat Sacraménto”. W znamiennym dla rytu szyku zostaje wskazane, że skaramentalne przeżycie tajemnicy jest sposobem, w jaki wierni zostają pouczeni i wzmocnieni. Nie powinni skupić wzroku tylko na tym, co „dane”, ale otworzyć się na to, co „przeżywane”, bo kosmowizja, którą operuje ryt, nie ogranicza się do znaku, lecz sięga jego znaczenia. Dlatego w innym miejscu inwokacja do Chrystusa zaczyna się od słów: „Zakończywszy tajemnice tej ofiary" (expletis sacrificiorum mysteriis) ${ }^{25}$.

Inny wariant opisujący wzajemne relacje „sakramentu” i „mysterium” ilustruje jedna z modlitw post sanctus z XIII niedzieli zwykłej: „Jezu Chryste, Synu Boga żywego i Panie Jednorodzony; który trwając z Ojcem, postanowiłeś odwiecznie złączyć się z Kościołem zgromadzonym spośród ludów i prawdziwie wyraziłeś tajemnicę tego zjednoczenia w tym sakramencie Twego Ciała i Twej Krwi; aby go rzeczywiście złączyć z sobą oczyściłeś go wodą chrztu, upiększyłeś olejem namaszczenia, nasyciłeś chlebem Twego Ciała i rozradowałeś go winem Twej przelanej Krwi; Ty sam byłeś jego Odkupicielem, Ty przemieniłeś siebie w cenę naszego okupu" 26 .

${ }^{25}$ In diem allisionis infantium, completuria: „Precamur, Domine Iesu Christe, ut expletis sacrificiorum mysteriis".

${ }^{26}$ In XIII dominica de cotidiano, post sanctus: „qui, cum Patre manens, æternitátis tuæ prospéctu definíeras unam tibi de géntibus congregándam Ecclésiam copuláre, cuius 
W sakramencie Eucharystii wyraża się głęboka tajemnica: euchologia nie tyle skupia się na kontemplacji natury obecności transcendentnego Pana pod postaciami chleba i wina, ile raczej na tajemnicy jedności Chrystusa ze swoim Kościołem, która sięga wieczności. Sakrament Ciała i Krwi Pana wskazuje na mysterium copulationis, złączenia się Chrystusa z Kościołem, które prawdziwie oddaje (vera exhibitione) jej najgłębszy sens ${ }^{27}$. Trudno nie oprzeć się wrażeniu, że euchologia rządzi się logiką Pawłowego mysterion, który oznacza realizację Bożego planu zbawienia ukrytego przed wiekami, a w pełni odsłoniętego w Chrystusie. Zdaje się na to wskazywać dalsza część modlitwy, która wspomina zbawcze zaangażowanie Chrystusa w celu przysposobienia Kościoła do pełnej wspólnoty z sobą: co znamienne, ta droga oczyszczenia, wzmocnienia i nasycenia Kościoła zostaje opisana przez odwołanie do sakramentów wtajemniczenia (chrzest, namaszczenie, eucharystia).

W mszy z piątku w oktawie Wielkanocy (In VI feria Paschae) dochodzi do głosu podobne pragnienie w oratio admonitionis, gdzie na kanwie ewangelicznej sceny cudownego połowu ryb mającego miejsce po zmartwychwstaniu zostaje wyrażona prośba, aby zostać zaliczonym do grona "mistycznych ryb" (inter mýsticos pisces, cibus esse Dómini). Droga do budowania autentycznej jedności prowadzi przez „kroczenie za prawdą cudownego sakramentu, kochając i zachowując przede wszystkim jedność" ${ }^{28}$. Okoliczności, w których przyszło żyć chrześcija-

copulatiónis mystérium in hoc sacraménto córporis et sánguinis tui vera exhibitióne complésti; ad inhæréndam tibi emúndans illam aqua baptismátis, exhílarans óleo unctiónis, sátians pane córporis et lætíficans vino effúsi cruóris, ipse Redémptor eius, ipse pro ea factus prétium emptiónis" (tłum. własne).

${ }^{27}$ Nie można zapominać o wyjątkowej naturze języka łacińskiego stosowanego w rycie hiszpańsko-mozarabskim, który cechuje się wielką obrazowością, narzędziami retorycznymi (zwłaszcza częstymi powtórzeniami) i odmiennym szykiem zdań. Por. M. C. Díaz y Díaz, El latín de la liturgia hispánica, [w:] Estudios sobre la Liturgia mozárabe, Toledo 1965, s. 55-87; C. Aillet, Les mozarabes: Christianisme, islamisation et arabisation en péninsule Ibérique (IXe-XIIe siècle), Casa de Velazquez, Madrid 2010.

${ }^{28}$ In VI feria Paschae, oratio admonitionis: „Subsequámur ígitur sacraménti admirábilis veritátem, diligéntes, ac tenéntes principáliter unitátem”. 
nom mozarabskim, przypominają o tym, że powinni trzymać się krzyża Chrystusa, czyli powinni pozwolić się wyłowić z morza jak ryby, aby zachować jedność w godzinie próby.

Podobny wątek eklezjologiczny pojawia się w illatio mszy uroczystości Objawienia Pańskiego (Apparitio Domini), gdzie ów wzniosły i przedziwny sakrament dotyczy zjednoczenia Chrystusa z Kościołem ${ }^{29}$. Dlatego Kościół zostaje zdefiniowany przez sakramenty: jego wyjątkowość płynie z faktu, że jest „jeden przez sakrament, nie przez miejsce” (singuláris sacraménto, non loco). Sakrament nie jest tylko powłoką misterium, skorupą chroniącą cenną zawartość, lecz źródłem przemieniającej mocy, „ut per transfusiónem cæléstis atque invisíbilis sacraménti”30. Dlatego

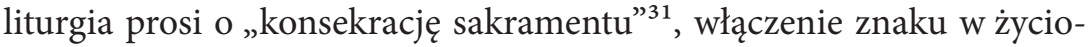
dajny strumień łaski.

\subsection{Mysterii recordatus: wymiar celebracyjny}

Świadomość, że liturgiczne zgromadzenie zostało zwołane, aby sprawować misteria, ujawnia się w wielu tekstach euchologicznych rytu mozarabskiego: nie jest zwykłym zebraniem wiernych, gdyż inter sacra mysteria constituiti. To ukonsytuowanie oznacza zakorzenienie i wpisanie w tajemnicę, a nie tylko jej zewnętrzne sprawowanie. Owe constituiti oznacza ostatecznie, że uczestnicząc w liturgii, zostaje wpisane w uprzywilejowaną przestrzeń dostępu do misterium, które nie jest czystą negatywnością (czego nie można poznać), lecz objawia swoją pozytywną moc, stając się okazją do poznania prawdy w całej jej głębi. Sięganie do tajemnicy to puls życia Kościoła, który postrzega siebie samego jako włączonego w misterium.

Zanurzenie egzystencji chrześcijańskiej w tajemnicach jest aktem konstytutywnym dla actio liturgica, określając jednocześnie tożsamość uczestników liturgii. Misteria, o których była mowa w oratio admonitionis, posiadają sens generyczny: nie chodzi o konkretne prawdy niedostępne dla ludzkiego

${ }^{29}$ In apparitione Domini, alia.

${ }^{30}$ In VII dominica de cotidiano, post pridie.

${ }^{31}$ In VI dominica de cotidiano, alia: „Mereátur petítio efféctum, contrítio solátium, consecrátio sacraméntum". 
intelektu, lecz bliskość Boga ukrytego, który daje się poznać w celebracji eucharystycznej, w słowie i działaniu sakramentalnym. Liturgia hiszpańska podkreśla w ten sposób powiązania misteriów z uroczystościami tworzącymi rok liturgiczny, troszcząc się o to, aby „celebrować ku czci Twego imienia misteria właściwe dla wszystkich celebracji” (ómnium sollemnitátum in tuo nómine mystéria celebráre $)^{32}$. Są to celebracje tajemnicy - mystérii sollemnitáte - „uroczystości, w których misterium staje się obecne”33. Dlatego właśnie liturgia będzie sytuować siebie w służbie pochłaniania odore fragrantia ${ }^{34}$, dobrego zapachu, woni misterium Boga, co skutkuje eksplozją radości i porywu serca w godzinie celebracji liturgicznej: „Wszyscy powinniśmy pragnąć tych chwil, w których zaprasza się ludzką słabość do uczestnictwa w tym wielkim i czcigodnym misterium, przez które Bóg skłania się do przyjęcia ofiary, którą składa mu człowiek" ${ }^{35}$. Dopowiedzmy, że ofiara rozumiana jest w kluczu nie tyle „poświęcenia czegoś cennego”, ile zawiązania relacji, ustanowienia komunikacji, wymiany. Nie zmienia to faktu, że człowiek służy Bogu w swym życiu, ale ta służba ma pewien odcień tajemnicy: „doskonale przedstawiając przed Tobą tajemnicę naszej służby (posługi)", jak modlą się mozarabowie w dniu wspomnienia Adriana, Natalii i towarzyszy (16 czerwca). Termin mysterium pojawia się z czasownikiem excolere ${ }^{36}$, invocare ${ }^{37}$, recordare $^{38} \mathrm{czy}$ celebrare $^{39}$ (w jego różnych derywatach), co ponownie podkreśla jego „przekazywalność" i pośredniczenie.

\subsection{Mysterium i objawienie}

W świetle hiszpańskich tekstów liturgicznych mysterium trzeba rozumieć w kontekście osobowym jako wzrastającą intymność interpersonalną

\footnotetext{
${ }^{32}$ In II Dominico de cotidiano, illatio.

${ }^{33}$ In diem conceptionis sanctoe Marice Virginis, post nomina.

${ }^{34}$ In diem Sancti Augustini, ad pacem.

${ }^{35}$ In I Dominico de cotidiano, oratio admonitionis.

${ }^{36}$ In V Dominico Paschae, illatio.

${ }^{37}$ In VI Dominico Paschae, oratio admonitionis.

38 Tamże.

${ }^{39}$ In Circumcisione Domini, oratio admonitionis.
} 
możliwą dzięki objawieniu, które wyraża intymność Trójcy Świętej. Dlatego ukryty charakter misterium wiąże się z intymnością życia trynitarnego i nie odnosi się jedynie do ograniczeń poznawczych ${ }^{40}$. Nie ulega wątpliwości, że mozarabowie widzieli w mysterium przede wszystkim moment „objawieniowy” komunikacji (podążając za modelem rozumienia tajemnicy, jaki spotykamy u św. Pawła), który ma za zadanie uczynić widzialnym to, co niewidzialne, przy całej świadomości niewystarczającego charakteru posiadanych środków ekspresji. Pojęcia i obrazy są tu użyte po to, aby wyrazić tajemnicę Boga, która nie jest jedynie czystym poznaniem, ale ożywiającym spotkaniem z łaską ${ }^{41}$ wzbogacającym życie chrześcijanina, gdyż fidei sacramenta locupletant ${ }^{42}$. To spotkanie ożywiające również dla rozumu, który na drodze ku pełnemu poznaniu Boga czuje się słaby i potrzebuje wsparcia łaski.

\section{Epistemologia mysterium: w stronę zbawczej rzeczywistości}

Mysterium to pewne excessum, nadwyżka znaczenia. Dlatego epistemologia liturgiczna rytu hiszpańskiego stawia akcent na zbawcze ukazanie się Boga w objawieniu ${ }^{43}$. Tajemnica nie chce zamknąć Boga w horyzoncie skończoności, jedynie wyeksponować Jego niepoznawalność, ukazać pozytywnie antropologiczne otwarcie człowieka na prawdę (co scholastyka oddaje przez capax veritatis) umożliwiającą wszelki postęp poznawczy. Ten głód prawdy zostaje zaspokojony przez wcielone Słowo Boga, które par excellence staje się mysterium. Dlatego właśnie tajemnica pozostaje w ścisłej relacji z wydarzeniem wcielenia, stając się niemal jego synonimem i często

${ }^{40}$ Por. A. Ivorra, Las illationes trinitarias del Missale Hispano-Mozarabicum y su relación con el prefacio romano de la Trinidad, „Toletana” 15 (2006), s. 49-58.

${ }^{41}$ Feria II in quarta hebdomada Quadragesime.

${ }^{42}$ In VI Dominico de Adventu, ad pacem.

${ }^{43}$ Por. R. Woźniak, Różnica i tajemnica. Objawienie jako teologiczne źródło ludzkiej sobości, W drodze, Poznań 2012. 
odnosząc się do najważniejszych zbawczych zdarzeń z życia Chrystusa. Doskonale ilustruje to pochwalna illatio z IV niedzieli wielkanocnej, gdy mówi o „wielkim i godnym podziwu misterium pobożności” (magnopietátis tuce ammirandóque mystério), rozumiejąc przez niego wcielenie, dzięki któremu Chrystus został - jak czytamy dalej - „manifestátus in carne, iustificátus in spíritu, osténsus in Ângelis, prædicátus in géntibus, créditus in hoc mundo, assúmptus in glória, de inférni nos perículis liberásti”44.

\subsection{Misterium jako manifestatio}

Dla Mozarabów mysterium to trynitarne ujawnienie się Boga na rzecz ludzi - On pozostaje w najgłębszym sensie Philantropos ${ }^{45}$. Z tego właśnie powodu epistemologia liturgiczna rytu nie tyle skupia uwagę na ludzkim wysiłku dosięgnięcia Boga, ile wskazuje na inny paradygmat: uczestnictwa w wiedzy, którą Bóg ma o sobie samym. Drogi tego uczestnictwa prowadzą przez moralny wysiłek „dostrojenia” umysłu do wzniosłych prawd, postawienia na dobrą dyspozycję moralną, dzięki której poszerzają się zdolności poznawcze człowieka. Dlatego misteria nie stanowią jakieś formy opresyjnej dla mozarabów, lecz paradoksalnie jako wyzwolenie, również to intelektualne. Poznanie misteriów wieńczy adoracja, ich proklamowanie zamienia się w hymn chwały i dziękczynienia.

Niemniej jednak objawienie misterium i jego liturgiczna proklamacja nie anuluje jego źródłowej misteryjności, ponieważ nie stanowią go jedynie rzeczy ukryte czy niezrozumiane. Nawet już ujęte (comprehensio) przez światło wiary nie tracą swej misteryjności. Misterium wzywa człowieka, aby postawił się coram Deo, ponieważ jest to najlepszy kąt, pod którym poznaje się prawdę. Ta nadzieja na pełne dotarcie do tajemnicy bazuje na tym, że Bóg jest secretórum ómnium cognitor znającym wszystkie sekrety ludzkiego losu, i tym, czego człowiek potrzebuje jest nie tyle pouczenie, ile miłość, która obejmuje świadomość i język, wyostrzy duchowe zmysły, pozwoli ustanowić odpowiedniość między hodie

\footnotetext{
${ }^{44}$ In IV Dominico Paschae, illatio.

${ }^{45}$ Por. A. Ivorra, Sentido espiritual del Padrenuestro en la liturgia hispana. El tiempo 'Cotidiano', „Estudios Trinitarios” 44 (2010), s. 494.
} 
celebracji i wiecznością Boga. Liturgia stwarza przestrzeń relacji z misterium, więzy afektywne i intelektualne, aby transmisja misteriów mogła się dokonać. Misterium domaga się więcej miłości, nie więcej poznania, gdyż miłość otwiera poznawczo.

Misterium podkreśla i broni transcendencji Boga wobec stworzenia, ale $\mathrm{z}$ drugiej strony przywołuje łaskę jako dar udzielonego poznania. Kształtuje uczestnika liturgii w tym duchu, aby uznał potrzebę objawienia, która nie jest zaniżaniem możliwości poznawczych, lecz uznaniem niewystarczalności. Ryt mozarabski dokonuje tego w sposób dla siebie właściwy, za pomocą pytań, jak wówczas, gdy zadaje pytanie samemu Bogu: „Quid poterit, o piisima Trinitas Deus noster, condigne tibi infirmitas humanae fragilitatis tribuere, quae tantis facinorum ponderibus praegravatur cotidie?"46.

\subsection{Poznać mysterium Christi}

Wśród misteriów najważniejsze miejsce zajmuje mysterium humanitatis Christi, które jest traktowane przez euchologię hiszpańską jako wydarzenie odnawiające człowieka, poszerzając horyzonty epistemologiczne, ponieważ tajemnice dzięki wcieleniu Chrystusa stają się jaśniejsze, dostępne: adventus sui, jak podkreśla jedna z modlitw, faciat mysteriis luminata ${ }^{47}$. Przyjęcie Chrystusa, którego liturgia nazywa Restaurator aeterne lucis, rozprasza mroki błędu siłą Jego światła.

Warto podkreślić, że logika misteryjno-sakramentalna wyraża istotną cechę wielkiego depozytu euchologicznego hiszpańskiego, wydobywając na światło dzienne szereg ważnych zagadnień teologicznych: transcendencję Boga i jego niezgłębione zamysły w stosunku do człowieka, skuteczność zbawczą tajemnicy wcielenia Słowa, darmowość udzielanych darów. Właśnie ta „niezasłużalność” darów sformułowana w formie doniośle brzmiącej zasady, że „łaska wyprzedza naturę” (gratia antevérteret natúram ${ }^{48}$ ), stanowi

${ }^{46}$ Littaniae ante diem sancti Cipriani, ad orationem Dominica.

${ }^{47}$ Ad nonan pro indulgentia, oratio.

${ }^{48}$ In diem Conceptionis Sanctoe Marice Virginis, alia: „Ineffábilis Deus Immaculátam Vírginem Maríam in mundi princípio prænuntiávit, sacratíssimum mystérium, cæléste 
background dla teologii tajemnicy. Aby dotrzeć do mozarabskiego rozumienia misterium, trzeba dobrze ulokować te współrzędne teologiczne rytu, które wydobędą szeroki zakres znaczeniowy konceptu.

Sakramenty pozostają w służbie misterium Chrystusa: dlatego liturgia $\mathrm{w}$ completurii mszy na rozpoczęcie nowego roku prosi, aby zasługi sakramentów Chrystusa (sacramentorum tuorum meritis) sprawiły, że wierni przejdą przez doczesne doświadczenia bez uszczerbku dla wiary ${ }^{49}$. Świadectwo życia zależy głęboko od przeżywania tajemnic Zbawiciela.

\section{3. Żyć na miarę tajemnicy: w stronę praxis eklezjalnej}

Dla liturgii mozarabskiej wspominanie misterium przekłada się na radykalną zmianę stylu życia, które stanie się egzystencją na miarę tajemnicy. W ten właśnie sposób oddaje tę praxis wypływającą $\mathrm{z}$ rozumienia misterium przywoływana już msza z piątku w oktawie Paschy: „Pro quibus mystériis ac miráculis hunc diem apud tuam cleméntiam sacrifíciis commendántes, pétimus a te, Redemptóre pio et Dómino, ut hodiérni mystérii recordátus, spólians nos véterem hóminem cum áctibus suis, índuas illum qui secúndum Dóminum creátus est, in iustítia et sanctitáte veritátis" ${ }^{50}$.

Zrzucenie z siebie „starego człowieka” przywołuje sakrament chrztu świętego, w którym wierzący zostaje zanurzony w tajemnicach Pana. Dokonuje się to dzięki wierze, której moc polega na tym, że włącza w intymne życie Boga. Jak zauważa Felix Maria Arocen ${ }^{51} \mathrm{w}$ ważnym studium dotyczącym fides w liturgii hiszpańskiej, wiara sprawia, że tajemnice zostają otwarte przed ochrzczonym, nie tyle w znaczeniu odarte $\mathrm{z}$ ich transcendencji, ile zostaje

prodígium, ut grátia antevérteret natúram".

${ }^{49}$ In initio anni, completuria.

${ }^{50}$ In VI feria Paschoe, alia.

${ }^{51}$ F. M. Arocena, Teologia simbolica della fede nel Missale Hispano-Mozarabicum, „Rivista litúrgica” 1 (2013), s. 185-203. 
uchylona szczególna ścieżka dostępu i penetracji misterium. Owocem tego obcowania z misterium jest również lepsze i głębsze poznanie samego człowieka, który posiada głód tajemnicy wyrażający się w jego zdolności do ciągłego przekraczania samego siebie. Podarowane światło nie oznacza, że nie istnieją ciemności, ale to, że nie do nich należy ostatnie słowo: to należy do fides integra, która stanowi klucz egzegezy liturgicznej dokonującej się w rycie hiszpańskim. Jej zadaniem jest odkrycie tego, co mozarabowie określali jako in illa mysticum ${ }^{52}$, jak wówczas, gdy podczas jednej z mszy w okresie wielkiego postu zaprasza się do zrozumienia perykopy o ślepym od urodzenia, który zostaje uzdrowiony przez Jezusa, jako obrazu obecnej sytuacji całej ludzkości: otwierające się oczy ślepca nie są w stanie znieść nadmiaru światła, nie widzi z początku ludzi (myśli, że to drzewa), aż jego wzrok przyzwyczaja się i dostrzega Jezusa. W tym obrazie został ukryty paradygmat życia liturgicznego mozarabów: celebracja sakramentalna misteriów to wpuszczanie światła, które przenika w głąb człowieka i otwiera go na pełne poznanie otaczającej go rzeczywistości. Światło pochodzi od Pana, to jest Jego inicjatywa - odpowiedzią człowieka jest troska, aby to światło - które można powiązać z sakramentami - nie zostało przyciemnione żadną przeszkodą.

\subsection{Participatio przez wiarę}

Spotkanie z tajemnicą dokonuje się poprzez wytrwałe uczestnictwo w powtarzających się celebracjach, które z racji ich częstotliwości nie powinny być niedoceniane, wręcz przeciwnie, jak podkreśla jedna z modlitw mozarabskich deseabile: częste uczestnictwo w celebracji wyostrza wrażliwość i moc intelektualną niczym wzrok, który musi dostroić się do obiektu, aby zaofiarować dobry obraz, o właściwej ostrości. Liturgia w ten sposób właśnie postrzega samą siebie, jako dającą „przystęp do tajemnicy Pana”

${ }^{52}$ In III Dominico de quadragesimae: „Erigámus, quæso, dilectíssimi fratres, corda nostra ad consideránda divini Mystérii sacraménta. Léctio étenim sancti Evangélii, quæ hodiérna die ad audiéndum vos fecit esse devótos effíciat étiam æternitátis frúctibus opuléntos. Et sicut audítu eam, fide íntegra percepístis, ita quoque fidéli devotióne quiddam in illa mýsticum requirátis". 
(accedéntes ad Dómini mystérium ${ }^{53}$ ), wzywając jednocześnie do „doceniania tajemnicy naszego odkupienia" (redemptiónis nostrce perpedéntes mystérium $\left.{ }^{54}\right)$. Znamiennie został tu użyty łaciński termin perpendentes, który oznacza dokładne ważenie, egzaminowanie: opisuje on adekwatną postawę wobec tajemnicy, którą powinni przyjąć mozarabowie. Próbować ogarnąć jej wagę, duchowy ciężar, nie traktować jako coś jasnego w sobie i raz na zawsze zamkniętego, ale ciągle czuć pewien niedosyt.

Odpowiedzią człowieka jest pragnienie, aby stać się uczestnikiem „sakramentów niebieskich": msza In Circumcisione Domini wiąże świętowanie tajemnicy wcielenia, przez którą dokonało się zbawienie z uczestnictwem w tym, co zawiera: ,caelestium sacramentorum participium consequi mereamur" Tej trosce o to, aby zasłużyć na uczestnictwo w sakramentach wtóruje zakończenie illatio - odpowiednika rzymskiej praefatio - z IV niedzieli wielkanocnej: „Per quam oríginem quamdam evangélicæ imitatiónis adépti, cæléstium secretórum sacraménta discéntes, laudes quas tibi in glória Patris cum Sancto Spíritu permanénti Ángeli et Archángeli canunt, nos quoque imitáti cæléstium beatitúdinem persolvámus cum Séraphim ita dicéntes" ${ }^{\prime 56}$.

Dzięki duchowemu błogosławieństwu spoczywającemu na eucharystycznych darach ofiarnych (niemających przecież żadnej solidnej materii, a którego siła pochodzi nie od niech właśnie!), rozpoczyna się droga ewangelicznego naśladowania, bycia uczniem, która zostaje scharakteryzowana jako uczenie się sakramentów tajemnic niebieskich.

\subsection{Liturgia w służbie arcana mysterii}

We wspomnianej illatio pojawia się termin secretorum, który nie tylko oddaje to, co zwykliśmy tłumaczyć jako sekret, ale także wskazuje na

${ }^{53}$ In XX Dominico de cotidiano, oratio admonitionis.

${ }^{54}$ In II Dominico quadragessimae, oratio admonitionis.

${ }^{55}$ In Circumcisione Domini, oratio admonitionis: „ut mystérium incarnatiónis eius pro nostræ salútis redemptióne celebrátum, áugeat in nobis gáudia nunquam ultérius finiénda, et vota multíplicet indisrúpta; ut dum offíciis impénsius mancipámur; cæléstium sacramentórum particípium cónsequi”.

${ }^{56}$ In quarto Dominico Paschae, illatio. 
inny niezwykle głęboki termin właściwy autorozumieniu liturgii: „ob arcana mysterii tui, Christe Domine Deus noster, a te collata inspiratione poscentes; deficit in contuitu acies, in intellectu visus, in relatione virtus, in narratione sermo" ${ }^{57}$. Posługując się terminem arcanum, ryt hiszpański chce zwrócić uwagę na centrum osobowe, gdzie tylko Bóg ma dostęp (stąd powiązanie z sekretem), ale także chodzi o głębię każdej celebracji (w tym znaczeniu pojawiają się określenia arcana paschalne). Wszystko po to, aby nie utracić z pola widzenia nastawienia na to, co zasadnicze, istotowe, co stanowi res, aby uwaga skupiona na signa nie stała się idolatryczna, odcięta od korzeni. Liturgia ma pozwolić temu, który w niej uczestniczy, na dostanie się do źródła misterium. Ta łączność z misterium wyznacza kanały eklezjalnej conversatio Dei - formy życia Kościoła, która odczytuje sens misteriów, wyłuskując go z opatrznościowego planu zbawienia: dlatego jedna z modlitw podkreśla: „qui Ecclésiam tuam sanctam cathólicam tanto eam tibi redemptiónis eius mysteriórum celebritáte iunxísti”.

\subsection{Dojrzewać do pełni misterium}

We mszy Apparitio Domini, przedstawiwszy w modlitwie post pridie różnorakie „ukazania się” Pana w toku Jego ziemskiego życia, Jego odsłonięcie się przed ludźmi w misteriach życia publicznego (narodzony z Dziewicy, ukazany pasterzom, poznany w mocy cudów, ogłoszony przez gwiazdę etc.), dostrzega w nich czytelną wskazówkę dla Kościoła, którego program tak formułuje ryt hiszpański: „ut sacrátæ sollemnitátis grátia ita suscípiat Ecclésia tua nunc gáudia, ut prætulit quondam mystéria"58. Łaska uroczystości ma pobudzić Kościół radujący się z obecności Pana, który daje się rozpoznać ludziom, do tego, aby niósł przed ludźmi owe misteria, gdyż są one dla nich światłem. Zastosowany tu czasownik praetulit (od praefero) oznacza „,antycypować, pragnąć, przyjąć”, co przekłada się na zadanie Kościoła, aby nieść te misteria Chrystusa do każdej z epok, nasiąknąć nimi niczym gąbka, antycypując w ten sposób - tak ważne dla liturgicznej wrażliwości mozarabskiej - ostateczne ukazanie się Pana

\footnotetext{
${ }^{57}$ In diem sanctorum Petri et Pauli, post pridie.

${ }^{58}$ In Apparitione Domini, Annus secundus, post pridie.
} 
w chwale. Wspomniana „łaska” celebracji dokonuje konfiguracji wiernych z Chrystusem, sprawiając, że postępują na drodze wiary ${ }^{59}$. Podkreśla to szczególnie liturgiczna egzegeza epizodu, który spotkał uczniów idących do Emaus: choć paradoksalnie wydaje się, że idą naprzód na swej drodze, to jednak - zauważa liturgia - cofają się na via fidei. Wówczas pojawia się Chrystus, który koryguje ich kurs i uzmysławia sens misterium ${ }^{60}$.

Dla wrażliwości mozarabskiej tajemnica nie jest zamkniętą rzeczywistością, lecz otwartą na jej liturgiczne dopełnienie. To dlatego czas adwentu, jak zauważa J. Pinell ${ }^{61}$, jest przeżywany w analogii nie tyle do okresu wielkiego postu, ile wielkanocnego: w obu przypadkach chodzi o dojrzewanie do pełni tajemnicy: wcielenia (mysterium pulchrum ${ }^{62}$ ) w adwencie i consumatio tajemnicy paschalnej w uroczystości Zesłania Ducha Świętego. Dlatego jedna z mszy odważa się mówić o wzroście wiary (wegetacji) we wspominane mysterium: „Semper quidem, dilectíssimi fratres, pia ad Dóminum gratulatióne, et sollícita ad Deum suum respícere debet afféctio. Sed nunc præcípue mens ardéntior, spes prómptior, fides præsénti mystérii recordatióne vegetátior...”. O ten właśnie wigor łaski sakramentu (vigeat gratia sacramenti) prosi liturgia ${ }^{63}$.

Uniwersytet Mikołaja Kopernika w Toruniu

KS. PIOTR ROSZAK

\section{Abstrakt}

Jedną z charakterystycznych cech hiszpańskiej euchologii jest jej akcent położony na misterium poznawane, przekazywane i partycypowane w rycie przez wiarę. Ten trójpodział

${ }^{59}$ J. J. Flores, La celebración de la eucaristía según el Misal Hispano-Mozárabe, „Nova et vetera" 46 (1998), s. 291-302.

${ }^{60}$ Więcej o charakterystyce egzegezy liturgicznej rytu hiszpańskiego por. F. M. Arocena, La misa hispanica Si credimus. Un ejemplo de la ruminatio litúrgica de la Escritura, „Scripta Theologica" 2 (2000), s. 631-642.

${ }^{61}$ J. Pinell, Liturgia hispánica, Centre de Pastoral Liturgica, Barcelona 1998, s. 25.

${ }^{62}$ In quinto Dominico Paschae, illatio.

${ }^{63}$ In I Dominico de cotidiano, alia. 
wyznacza rytm refleksji nad pojęciem tajemnicy w rycie hiszpańsko-mozarabskim, który został przedstawiony w niniejszym artykule. Dlatego przede wszystkim zostało ukazane, że liturgia mozarabska jest ukierunkowana ad consideranda divinis Mysteriis sacramenta. To słowne połączenie terminów mysterium oraz sacramentum jest charakterystyczne dla tego rytu i ustanawia właściwe współrzędne hermeneutyczne dla epistemologii liturgicznej. Te dwa pojęcia nie są jeszcze synonimami, a bardziej wskazują na dwa różne aspekty: zewnętrzny (znak) oraz wewnętrzny (rzeczywistość zbawcza mediatyzowana w rycie). Liturgiczna actio otwiera przestrzeń i czas, aby w widzialnych znakach uczestnik liturgii odkrywał niewidzialną rzeczywistość. Po drugie, dla mozarabów misterium nie wyraża jedynie prawdy o niepoznawalności Boga, lecz wskazuje na Jego trynitarne odsłonięcie, objawienie. Wreszcie, euchologia hiszpańska jest naznaczona troską o adekwatne świętowanie mysteriis solemnitatis, co można tłumaczyć jako łaskę sakramentalną oraz o zachowania odore fragrantia mysterium. Życie chrześcijańskie jawi się w tej perspektywie jako przeżywanie tajemnic, które Bóg zechciał dzielić z człowiekiem. Wprowadza to eklezjalny paradygmat mądrości, który obejmuje liturgię rozumianą jako arcanum Christi.

\section{Słowa kluczowe}

Ryt hiszpańsko-mozarabski, chrystologia, tajemnica, sakrament

\section{Abstract}

\section{Mysterium in Hispanic-Mozarabic euchology: from liturgical epistemology to ecclesiological praxis}

One of the characteristics of the Hispanic euchology is its focus on the mystery known, mediated and participated in the rite by faith. This tri-partite division will determine our reflection on mystery. First, Mozarabic Rite is oriented ad consideranda divinis Mysteriis sacramenta. It is very typical for this rite this verbal unit between mystery and sacrament, which establishes the appropriated hermeneutical coordinates for the liturgical epistemology. These two terms are not already synonyms, since they indicate two different aspects, external (sign) and internal (salvific reality), mediating in rite. Liturgical actio opens up space and time so that, under visible signs, one can discover the invisible mystery. Second, for Mozarabs, the mystery is not so much a reminder of the unknowability of God but 
means his Trinitarian revelation. Finally, the Hispanic euchology is marked by concern for adequately celebrating mysteriis solemnitatis, the grace of sacraments, and intends to hold the odore fragrantia of mystery in the rite. The Christian life is view as the bringing of mysteries which God wanted to share with man. It introduces the ecclesial paradigm of wisdom, which entails liturgy comprehended by Mozarabs as arcanum Christi.

\section{Keywords}

Hispanic-mozarabic rite, christology, mystery, sacrament

\section{Bibliografia}

Aillet C., Les mozarabes: Christianisme, islamisation et arabisation en peninsule Iberique (IXe-XIIe siecle), Casa de Velázquez, Madrid 2010.

Arocena F. M., La misa hispanica Si credimus. Un ejemplo de la ruminatio litúrgica de la Escritura, „Scripta Theologica” 2 (2000), s. 631-642.

Arocena F. M., Teologia simbolica della fede nel Missale Hispano-Mozarabicum, „Rivista litúrgica" 1 (2013), s. 185-203.

Beale-Rivaya Y., The history and evolution of the term "mozarab”, „Imago Temporis. Medium Aevum" 4 (2010), s. 51-71.

Breviarium Goticum secundum Regulam Beatissimi Isidorii, Edición facsímil, ed. J. Paniagua, Universidad de Leon 2004.

Christys A., Christians in Al-Andalus 711-1000, Routledge, London-New York 2010.

Díaz y Díaz M. C., El latín de la liturgia hispánica, [w:] Estudios sobre la Liturgia mozarabe, Toledo 1965, s. 55-87.

Ferrer J. M., La Eucaristía en rito hispano-mozárabe. Gestualidad y ambiente para la celebración, „Toletana” 1 (1999), s. 59-88.

Flores J., La celebración de la Eucaristía según el Misal Hispano-Mozárabe, „Nova et vetera" 46 (1998), s. 291-302.

Gallego M. A., The languages of medieval Iberia and their religious dimension, „Medieval Encounters" 1 (2003), s. 107-139.

Ivorra A. V., Sentido espiritual del Padrenuestro en la liturgia hispana: el tiempo 'Cotidiano', „Estudios Trinitarios” 44 (2010), s. 471-495. 
Ivorra A., Las illationes trinitarias del Missale Hispano-Mozarabicum y su relación con el prefacio romano de la Trinidad, „Toletana” 15 (2006), s. 49-58.

Janeras V., Elements orientals en la liturgia visigótica, [w:] Miscelanea Liturgica Catalana VI, Institut d'Estudis Catalans, Barcelona 1995, s. 93-127.

Lapiedra E., Como los musulmanes llamaban a los cristianos hispánicos, Alicante 1997.

Lázaro M., Cristianismo e Islam en el pensamiento medieval. Encuentros y desencuentros, „Cauriensia” 4 (2009), s. 81-139.

Pedrajas R. J., Historia de los mozárabes en Al Andalus: mozárabes y musulmanes en Al-Andalus: ¿relaciones de convivencia?, ¿o de antagonismo y lucha?, Almuzara, Córdoba 2013.

Penarroja L., Cristianos bajo el Islam: los mozárabes hasta la Reconquista de Valencia, Gredos, Madrid 1993.

Pinell J., Hispánica (liturgia), [w:] Diccionario Patrístico y de la Antigüedad Cristiana, dir. A. Di Bernardino, vol. II, Sígueme, Salamanca 1998, 1048-1054.

Pinell J., Liturgia hispánica, Centre de Pastoral Litúrgica, Barcelona 1998.

Ranera L., Jesús y Mahoma, „Encuentros Teológicos” 7 (2007-2008), s. 106-109.

Rivera Recio J., Formas de convivencia y heterodoxias en el primer siglo mozárabe, [w:] Historia mozárabe, Instituto de Estudios Visigotico-Mozarabes de San Eugenio, Toledo 1978, s. 3-16.

Roszak P., La fe: entre manifestación y secreto. En torno a la eucología hispano-mozárabe, "Scripta Teológica” 1 (2014), s. 39-58.

Roszak P., Mozarabowie i ich liturgia. Chrystologia rytu hiszpańsko-mozarabskiego, Wydawnictwo Naukowe UMK, Toruń 2015.

Roszak P., Mozarabowie - niespokojna mniejszość. O duchowości czasów bycia w mniejszości, „Teologia i Człowiek” 13 (2009), s. 79-98.

Urvoy D., La pensee religieuse des Mozarabes face a l'Islam, „Traditio” 39 (1983), s. 419-432.

Woźniak R. J., Różnica i tajemnica. Objawienie jako teologiczne źródło ludzkiej sobości, W drodze, Poznań 2012. 